\title{
Effects of Luminaire Angle on Illumination Performance in Tunnel Lighting
}

\author{
M. S. CENGIZ
}

\begin{abstract}
In this study, the effect of luminaire angle on the path parameters of tunnel lighting was investigated. Tunnel illumination was performed with a simulation program adapted to CIE 88-2004 standards. The lighting performance parameters were compared while the angle of the luminaire was $0^{\circ}, 5^{\circ}, 10^{\circ}$ and $15^{\circ}$. According to the simulation results, the luminaire angle is $0^{\circ}$ and the highest efficiency is reached. As the luminaire angle increased, the yield decreased in direct proportion to the angle. The highest lighting efficiency was observed at $0^{\circ}$ and the lowest illumination efficiency was observed at $15^{\circ}$. This problem can be overcome by using a higher power lamp in angled lighting. As a result, it is revealed that angled lighting should be avoided in highway and tunnel lighting.
\end{abstract}

Index Terms-Illumination, luminance, road lighting, tunnel lighting.

\section{INTRODUCTION}

$\mathrm{T}$ UNNELS ARE underground road structures which are alternative to highways and railways. They are used to facilitate traffic flow. Tunnels, should ensure the visibility comfort, speed and safe traffic flow. If the tunnel lighting does not illuminate as much as necessary, a driver approaching the tunnel experiences a black hole effect. Therefore, intense lighting should be done at the entrance of the tunnel. Intensive lighting is not required in the interior of the tunnel [1-3].

In long tunnels, the tunnel interior area is an important part of tunnel lighting cost. Therefore, for the most appropriate tunnel illumination that provides economic but necessary vision conditions, the brightness level in the tunnel interior should be determined correctly. The driver using any vehicle on highways should have detailed visual information about the way in which he is driving. Especially at high speeds, the driver should be able to see the route easily, the driver should be able to perceive the position and movements of the vehicle he is driving, be able to monitor the movements of other vehicles, and easily be able to see the obstacles on the road [46].

MEHMET SAIT CENGIZ, is with Department of Technical Vocational School of Bitlis Eren University, Bitlis, Turkey, (e-mail: msaitcengiz@gmail.com).

iD https://orcid.org/0000-0003-3029-3388

Manuscript received May 10, 2019; accepted June 10, 2019.

DOI: $\underline{10.17694 / \text { bajece. } 563021}$
CIE reports the results of 30 different studies, covering road lighting studies that improve vision conditions. In this report, according to the standards of road lighting: pedestrian accidents from $57 \%$ to $45 \%$, fatal accidents from $65 \%$ to $48 \%$, severe injuries from $30 \%$ to $24 \%$, and the total number of accidents it decreased from 53\% to $14 \%$ [7, 8]. Even if there is little traffic at night, the number of accidents that occur in roads or tunnels without illumination is about three times higher than in daylight hours. The reason for this is the lack of road lighting in accordance with the standards. Figure 1 shows traffic accidents in the tunnel.

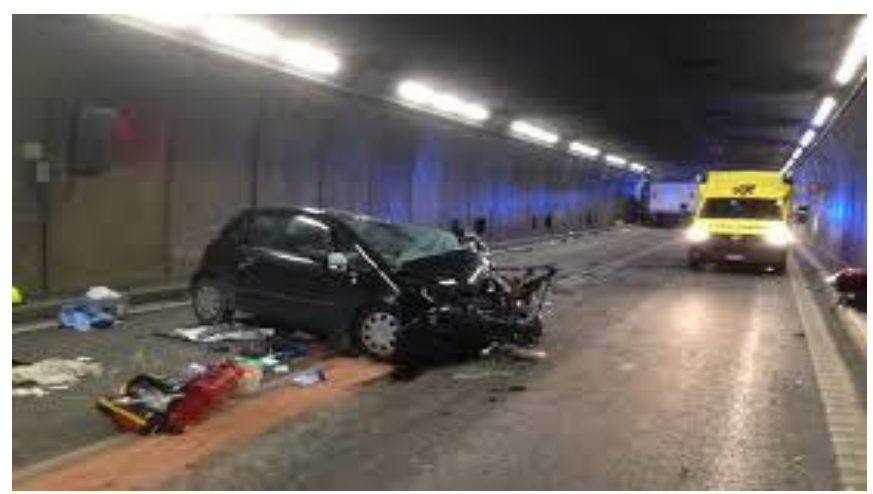

Fig.1. Traffic accidents in the tunnel

Tunnel lighting design calculations performed in this study are based on the recommendations involved in the technical report "Guide for The Lighting of Road Tunnels and Underpasses" CIE-1990 dated 2004 No-88. Conducting appropriate road lighting to the CIE reduces the rate of crime committed in city roads. According to the studies in the literature, the number of forensic cases has decreased by $20 \%$ in urban roads thanks to the proper lighting. The severity of offenses has decreased by $40 \%$. In the severity of crimes committed, it was seen that there was a $40 \%$ decrease [8-10].

\section{TUNNEL Vehicle TRANSITION ZONES}

Tunnel lighting is examined by classifying different luminance zones in order to ensure adaptation and provide economic solutions. Figure 2 shows zones of the tunnel. 


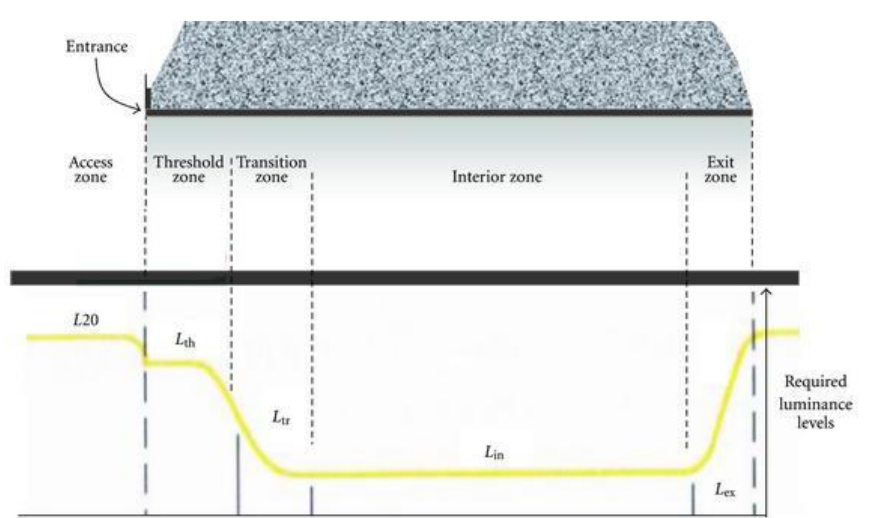

Fig.2. Zones of the tunnel

The access zone is the area starting before the tunnel entrance (100-200) $\mathrm{m}$ and ending at the tunnel entrance. There are two factors affecting the adaptation luminance:

- Around the tunnel entrance, "equivalent veiling luminance" $\left(L_{\text {seq }}\right)$ formed by different luminance values;

- Luminance at the centre of the driver's field of view. Equivalent veiling luminance is one of the most important factors in determining adaptation of the driver [1-2, 11-13].

Entrance zone is the place where adaptation accurately starts from the tunnel entrance and continues to the interior zone of the tunnel. It is examined in two different zones:

- Threshold zone: limits of the zone starting from the tunnel entrance are determined on the basis that a critical object that may be dangerous in that zone can be seen by the driver in the approach at least from a distance equal to the stopping distance;

- Transition zone: after the threshold zone, the transition zone is where the luminance in the threshold zone is reduced to a luminance level in the interior zone. The length of the zone varies by the initial and final luminance value and the allowed speed limit.

- Interior Zone: the constant luminance zone between entrance and exit zones of the tunnel.

- Exit Zone: the zone from the end of interior zone to the exit that makes the adaptation easier to the zone with high luminance at the exit $[1-2,11-13]$.

\section{DETERMINATION OF THE ACCOUNT AREA FOR TUNNEL LIGHTING}

In this study, Point Lighting Account Method is used on road surface. In this method, firstly the area to calculate the spot lighting is selected. The area between the two pole is determined as the account area. Starting from the first armature in the calculation area, point calculation is made according to the observer which is positioned $60 \mathrm{~m}$ backward and in the middle of each strip. The luminance level of a point on the road surface is equal to the sum of the light levels that come to a point $[6,14,15]$. Figure 3 shows a sketch of a point lighting calculations.

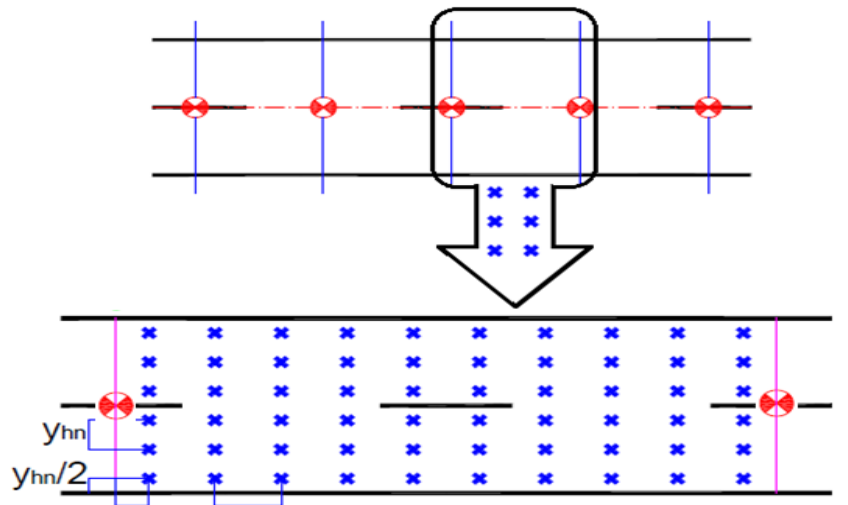

Fig.3. A sketch of a point lighting calculations

Calculations are based on a period for periodic and linear paths. If you have more than one periodic and linear path pieces on the road, you need to make a separate calculation for each part of the road. Radius greater than $300 \mathrm{~m}$ radius can be considered as linear path. The area between the two light sources on the single roads is considered the account area. On double roads (refugee), the area between two light sources is considered as the area of account, considering only one of the routes of departure or arrival. Only one side calculation is sufficient [16-23].

In this study, lighting calculations are made for tunnel inner zone. Tunnel inner region is the place where energy consumption is the highest in long tunnels.

The horizontal illuminance of a point $\mathrm{P}$ on an illuminated path; This is the sum of the horizontal light levels that all the luminaires affecting the account area in the lighting installation formed at this point. Figure 4 shows the horizontal illumination level vector state $[14,15]$. Equation 1 shows the correlation between horizontal illumination levels.

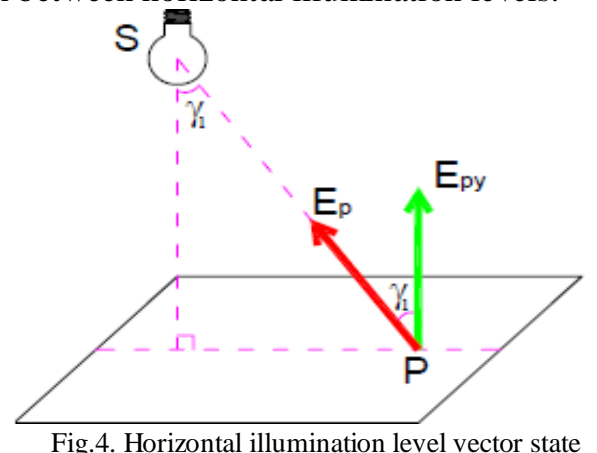

$E_{p \gamma}=\sum_{i=1}^{a} \frac{\Phi_{L} \cdot M F \cdot \mathrm{I}\left(C, \gamma_{2}\right)}{1000 \cdot h^{2}}$

$\mathrm{I}(\mathrm{C}, \gamma)$ : is value of light intensity reaching from luminaire i to point $\mathrm{P}(\mathrm{cd})$,

$\gamma$ : is angle of gleam falling within point $\mathrm{P}$ by the vertical line,

a: is amount of luminaires contributing to point $P$,

$\mathrm{h}$ : is ground clearance of luminaire photometric center $(\mathrm{m})$

$\mathrm{C}$ : is plane angle,

MF: Maintenance factor. 


\section{TUNNEL LUMINANCE}

The most important objective to design lighting systems is to obtain sufficient light without supplying excessive lighting and increasing energy cost $[1,2,6]$. Luminance is the most important dimension in terms of light effect on a road. Luminance is indicated by $\mathrm{L}$ and the unit is $\mathrm{cd} / \mathrm{m}^{2}$. A smooth luminance distribution as much as possible on the road surface should be ensured for the good visibility of the objects and the driver's visual comfort. Today, road lighting is based on Luminance Method which is based on road surface glow. The horizontal illuminance of a point $\mathrm{P}$ on an illuminated road; It is the sum of the horizontal illuminance levels that all the light sources acting at point $P$ have at this point $[1,2,6,14,15]$. In Equation 2, the relation between the variables to be used in the calculation of $\mathrm{P}$ point luminance is seen.

$$
E_{p \gamma}=\sum_{i=1}^{a} \frac{\Phi_{L} \cdot M F \cdot \mathrm{I}\left(C, \gamma_{2}\right)}{1000 \cdot h^{2}}
$$

A fluorescent lamp has a glow of $5000-15000 \mathrm{~cd} / \mathrm{m}^{2}$, a full moon has a glow of $2500 \mathrm{~cd} / \mathrm{m}^{2}$ and a road surface under 30 lux of lighting has a glow of $2 \mathrm{~cd} / \mathrm{m}^{2}$. Since the glitter concept involves a specific point of the surface and observation direction, it is necessary to identify these conditions when glitter is mentioned. The glow of ideal reflective surfaces can be calculated by benefiting from the illumination level $[1,2]$. When $\rho$ is the reflection factor of the surface, the relation between glitter and illumination level is determined by Equation 3.

$$
L=\rho \frac{E}{\pi}
$$

The mean road level luminance $\left(L_{t h}\right)$ in any point of the threshold zone (it is the first extension at the tunnel entrance in Figure 5) is called the threshold zone luminance [3-5].

The rate of the threshold zone and access zone luminance's is $k=L_{t h} / L_{20}$, where $\left(L_{t h}\right)$ is the mean road surface luminance at the beginning of the threshold zone and $\left(L_{20}\right)$ is the luminance distance equal to the stopping distance in front of the tunnel. The mean value of the road surface luminance at any point of the transition zone is called the transition luminance $\left(L_{t r}\right)$. The value of the mean road surface luminance in the interior zone is called the interior zone luminance $\left(L_{\text {in }}\right)[1,2,6,14,15]$.

\section{IV.1 Average road surface luminance}

In the road lighting, the fund of objects is the road surface that forms the driver's field of vision. Therefore, a higher Laverage makes it easier to see by providing a higher background glow. The increase in $L_{\text {average }}$ increases the sensitivity of the driver's eye by increasing the luminosity of the objects in the road. Therefore, the most important parameter for detection is $L_{\text {average }}$. $L_{\text {average }}$ is calculated using the glitter values on the selected $m x n$ pieces on the road. For $L_{\text {average }}$, the luminance values of all the light sources affecting the account area are calculated and collected as vector. In this way, the glare value at each point is calculated. The average surface road luminance is calculated separately for each observer $[1,2,6,14,15]$.

\section{IV.2 Uniformity}

Even though lighting systems provide a good mean road surface luminance, there may be zones with low luminance where contrast is weak and small obstacles cannot be detected. The difference between minimum and mean road surface luminance's into the field of view is expected to be lower than a certain value in order to obtain enough illumination at all points on the road. This obligation brings us to the overall uniformity and longitudinal uniformity values that are important secondary parameters.

There should be an equal distribution of luminance in the road (on the road surface) in order to provide a clear view for the driver. Two kinds of uniformity are considered important in tunnel lighting [7-10]:

1) Mean (resultant) uniformity $\left(U_{o}\right)$ : When traffic is on the right side, it is the rate of minimum luminance $\left(L_{\min }\right)$ to mean luminance of the road $\left(L_{\text {average }}\right)$, which is determined by an observer at $1 / 4$ distance of the road width on the right side of the road. The lower sections of the walls should be considered as well as road surface $[1,2,6,14,15]$. Equation 4 presents the ratio suitable for the road surface and mean luminance uniformity of the walls up to $1.5 \mathrm{~m}$ from the ground according to CIE 140-2000 and CIE 88-2004 [24, 25].

$$
U_{o}=\frac{L_{\min }}{L_{\text {average }}} \geq 0.4
$$

Longitudinal uniformity $\left(U_{l}\right)$ : According to an observer on the center line of road lane, it is the rate of minimum luminance applied through the center line to maximum luminance. Equation 3 presents the rate suitable for longitudinal uniformity through the road. Equation 5 shows change of longitudinal uniformity factor.

$U_{I}=\frac{L_{\min }}{L_{\max }} \geq 0.7$

\section{IV.3 Surround rate}

Light sources illuminate the emergency lane or pavement at a certain rate when illuminating the road surface. The parameter defined for this is the surround rate (SR).

\section{IV.4 Light sources}

High-pressure sodium vapor (HPS) lamps are preferred under conditions of higher luminance level, including under water tunnels, as HPS lamps have higher light flux and smaller dimensions than low-pressure lamps. As a result, less luminaries and area are required for lighting. The luminance efficiency is defined as the luminance level from the power required for the road (for $1 \mathrm{~m}^{2}$ ). In this study, $50 \mathrm{~W}$ HPS lamp was used. The lamp is luminous flux 4000. 


\section{DETERMination OF THE ACCOUNT AREA FOR TUNNEL LIGHTING}

Road types are defined in international technical reports and an optimal solution range is presented technically for these road types. The required design calculations should be made through luminaries with known photometric values, and the number and type of the luminaries should be determined according to these calculations [8, 20, 26-31].

Related road, road lighting class is determined by the table in the CIE 115-2010 [8, 20, 27]. According to Table 1, road lighting class M2 was found. Road lighting class selection parameters are shown in Table 1. Road lighting quality parameters are shown in Table 2.

TABLE I

ROAD LIGHTING CLASS SELECTION PARAMETERS

\begin{tabular}{|c|c|c|}
\hline Parameter & Options & Weight factor \\
\hline Speed & High & 0.5 \\
\hline Traffic jam & High & 0.5 \\
\hline Traffic layout & Only motor vehicles & 0 \\
\hline Middle median strip on the road & Yes & 1 \\
\hline Intensity of intersection & High & 1 \\
\hline Parked vehicle & No & 0 \\
\hline Environmental lighting & High & 1 \\
\hline Traffic control & Medium or good & 0 \\
\hline \multicolumn{2}{|c}{ Total of weight factors: } & 4 \\
\hline
\end{tabular}

Road lighting class was found with equality 6,7 and 8 . Road lighting quality parameters are shown in table 4 [8, 20, 27].

$$
\begin{aligned}
& M X=6-\text { Total weight factors } \\
& M X=6-4=2 \\
& M X=M 2
\end{aligned}
$$

TABLE II

ROAD LIGHTING QUALITY PARAMETERS

\begin{tabular}{|c|c|c|c|c|c|}
\hline Lighting class & $L_{\text {average }}$ & $U_{O}$ & $U_{I}$ & $T I \%$ & $S R$ \\
\hline $\mathrm{M} 2$ & $>1,5$ & $>0,4$ & $>0,7$ & $<10$ & $>0,5$ \\
\hline
\end{tabular}

\section{V.1 Features of the tunnel lighting}

The road pavement is asphalt, class R4. Additionally, $\mathrm{Q}_{0}=0.08$, the wall coating is concrete, the reflectivity is 0.4 , and the height of the luminary is $11 \mathrm{~m}$. The maintenance factor of the luminary is 0.83 and all calculated luminance values are corrected. The ratio of the smallest luminance value to mean luminance value is greater than 0.4 in the calculations for road lighting, ensuring that the rate of the smallest luminance value to the largest at the latitude coordinate of the observer is greater than $0.7\left(U_{I} \geq 0.7\right)$.

The luminance levels and uniformities of the tunnel walls are in accordance with relevant standards and thay are very important for driving safety. All lighting luminaries were established in single line $2 \mathrm{~m}$ from the tunnel walkways to the axis of the road and at a height of $6 \mathrm{~m}$. The lighting in the tunnel will be supplied by the luminaries with symmetric light distribution. The contrast revealing coefficient, which is the most important criterion in the application of symmetric light distribution, is less than 0.2 . Table 3 illustrates the road and lighting parameters [20-22, 29, 30].
TABLE III

TUNNEL AND LIGHTING PARAMETERS

\begin{tabular}{|l|c|l|c|}
\hline \multicolumn{4}{|c|}{ Tunnel lighting parameters } \\
\hline Lighting pole type & Galvanized & Lighting class & M2 \\
\hline Number of road lanes & 1 & Console length (m) & - \\
\hline Strip Width (m) & 4 & Console Angle & - \\
\hline Road Width (m) & 4 & Armature Angle & $0^{\circ} / 5^{\circ} / 10^{\circ} / 15^{\circ}$ \\
\hline Road Class & R4 & Lamp type & HPS \\
\hline$Q_{o}$ & 0.08 & Lamp power(Watt) & 50 \\
\hline Distance to illumination & 0 & Lamp luminous flux & 4000 \\
\hline $\begin{array}{l}\text { Illumination height from } \\
\text { ground (m) }\end{array}$ & 6 & $\begin{array}{l}\text { Maintenance factor } \\
\text { (every 3 years) }\end{array}$ & 0.83 \\
\hline
\end{tabular}

\section{V.2 Simulation study}

A non-commercial simulation program was used for lighting in this study $[1,29,30]$. The main purpose of the new studies is to reach the most economical results that provide adequate conditions. In the new study's made about road lighting, classifications are taken into consideration in the various scenarios conditions. The most accurate reference to road-tunnel lighting are international standards. For this reason, simulation is adapted to CIE standards. According to CIE 140 - CIE 88, the luminance values, averaged luminance level, averaged and longitudinal uniformity values of all points were calculated for the observers [24, 25].

Luminaires to be used in road-tunnel lighting should be chosen by taking into account glare level, luminance level of the road, lighting uniformity and economy, and they should be determined in consequence of computer calculations according to the luminance method [30-37].

Various choices are available for the road parameters in the simulation program. For the road-tunnel parameters, the lighting system (mutual, cross, divided road, road with single luminary, road with two luminaries, etc.), road class (R1, R2, R3, R4, N1, N2, N3, N4, etc.), number of lanes, lane width, refuge width, and road lighting class (M1, M2, M3, M4, M5, M6, etc.) can be chosen. For the lighting parameters, features such as distance between the luminaries, height of the luminary, distance of the luminary from the road, console angle, IP protection class, pollution rate, cleaning period, and maintenance factor are chosen for post or hanger system lighting. For the luminary parameters, the name, angle of the luminary (angle relative to the road), power of the lamp used, lifetime, light flux, ballast power, and new lamps can be added into this simulation under the Database process at any time. As a result, it is possible to add any kind of lamp into the simulation $[1,2,29,30]$. An easy and accurate calculation is achieved in the simulation results for the lighting system in which data is entered.

\section{APPLICATIONS OF TUNNEL LIGHTING}

In this study, a problem encountered in tunnel lighting were investigated. These problem are about angled lighting. For this purpose, it has been proven with a simulation program that the angled lighting encountered almost everywhere in the road lighting is inaccurate [30-37]. It is proved that it is necessary to perform $\left(0^{\circ}\right)$ illumination parallel to the road surface instead of angled lighting. New solutions can be found in the simulation environment for roads with different strengths and 
lamps with different strengths, as in this example.

\section{VI.1 Angle effect in lighting}

Various design tools or physical measurements are used in order to determine illumination level of certain points selected in lighting systems. These are physical measurements carried out by models, numerical equations and computer programs or by luxmeter in real environment. In this study, HPS 50W lamp luminaires inserted dually $6 \mathrm{~m}$ high are used in the road. Determination of luminaire angle $\left(0^{\circ}, 5^{\circ}, 10^{\circ}\right.$ and $\left.15^{\circ}\right)$ for a 50W HPS lamp luminaire with protection class IP65 is calculated simulation.

Today, the most important problem in energy is efficiency [33-42]. It causes loss efficiency of angled lighting. Efficiency loss was calculated on the basis of simulation. As the angle increased, the luminance efficiency in the road decreased. Fig. 5 shows efficient and inefficient (angle) lighting.

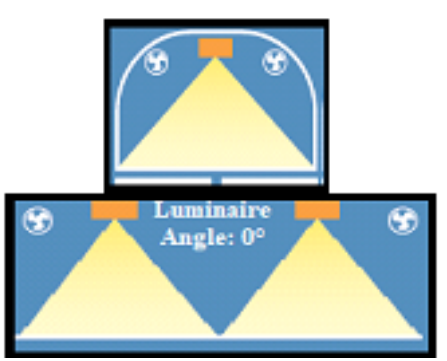

a) Efficient lighting

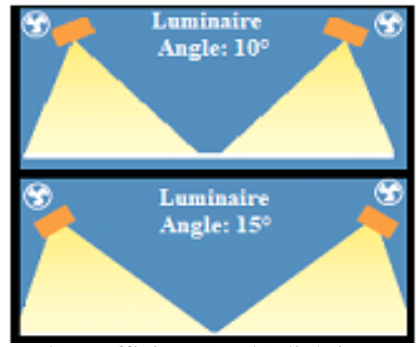

b) Inefficient (angle) lighting
Fig.5. Efficient and Inefficient (angle) lighting

In this study, a single-lane road which is suitable for CIE 88-2004 The Lighting of Road Tunnels and Underpasses has been investigated in the simulated environment. Calculations were made at $0^{\circ}, 5^{\circ}, 10^{\circ}$ and $15^{\circ}$ angles for $50 \mathrm{~W}$ HPS lamp. With the exception of $0^{\circ}, 5^{\circ}, 10^{\circ}$ and $15^{\circ}$ angles illumination has been found to cause loss of efficiency. For example, luminaire angle $=0^{\circ}$ while $L_{\text {average }}=1.51 \mathrm{~cd} / \mathrm{m}^{2}$. This corresponds to CIE 88-2004 standard The Lighting of Road Tunnels and Underpasses for M2 (While the distance between the poles is $11 \mathrm{~m}$ ) [10]. Luminaire angle is $5^{\circ}, 10^{\circ}$ and $15^{\circ}$ $L_{\text {average }}$ is less than $1.50 \mathrm{~cd} / \mathrm{m}^{2}$ (While the distance between the poles is $11 \mathrm{~m}$ ). If $L_{\text {average }}=1.50 \mathrm{~cd} / \mathrm{m}^{2}$ less than the lighting is not suitable for CIE 88-2004 standard. Table 2 shows the requirements for lighting class:M2. Table 4 shows tunnel lighting results for $0^{\circ}, 5^{\circ}, 10^{\circ}$ and $15^{\circ}$ angles.
TABLE IV

TUNNEL LİGHTING RESULTS FOR $0^{\circ}, 5^{\circ}, 10^{\circ}$ AND $15^{\circ}$ ANGLES

\begin{tabular}{|c|c|c|c|c|}
\hline Angle of illumination (Degree) & $0^{\circ}$ & $5^{\circ}$ & $10^{\circ}$ & $15^{\circ}$ \\
\hline Observer location (m) & 2 & 2 & 2 & 2 \\
\hline$L_{\text {average }}$ & 1,51 & 1,36 & 1,16 & 0,95 \\
\hline$U_{o}$ & 0,59 & 0,55 & 0,53 & 0,52 \\
\hline$U_{l}$ & 0,77 & 0,83 & 0,78 & 0,81 \\
\hline$T I \%$ & 3,2 & 3,0 & 3,0 & 3,1 \\
\hline$E_{\min }$ & 15,94 & 13,23 & 10,98 & 9,67 \\
\hline$E_{\max }$ & 41,4 & 41,11 & 36,85 & 29,36 \\
\hline$E_{\text {average }}$ & 29,08 & 26,37 & 22,52 & 18,45 \\
\hline$U_{o a}$ & 0,55 & 0,51 & 0,5 & 0,54 \\
\hline$U_{l a}$ & 0,38 & 0,32 & 0,3 & 0,33 \\
\hline$S R$ & 0,53 & 0,64 & 0,78 & 0,94 \\
\hline Lamp power (W) & \multicolumn{5}{|c|}{50} \\
\hline Luminous flux & \multicolumn{5}{|c|}{11} \\
\hline Distance between illuminations(m) & \multicolumn{5}{|c}{} \\
\hline
\end{tabular}

For Table 4; if the $L_{\text {average }}$ for $0^{\circ}$ is accepted $100 \%$;

- The loss rate for luminaire angle $=5^{\circ}$ is approximate $10 \%$.

- The loss rate for the luminaire angle $=10^{\circ}$ is approximate $23 \%$.

- The loss rate for the luminaire angle $=15^{\circ}$ is approximate $37 \%$.

Table 5 shows illuminance level for tunnel lighting (luminaire angle: $0^{\circ}$ ). Table 6 shows luminance (luminaire angle: $0^{\circ}$ ) for tunnel lighting. Tables 7,8 and 9 show the luminance (luminaire angle: $5^{\circ}, 10^{\circ}$, and $15^{\circ}$ respectively) for tunnel lighting. The change of the lighting parameters according to the luminaire angles is shown in Figure 6.

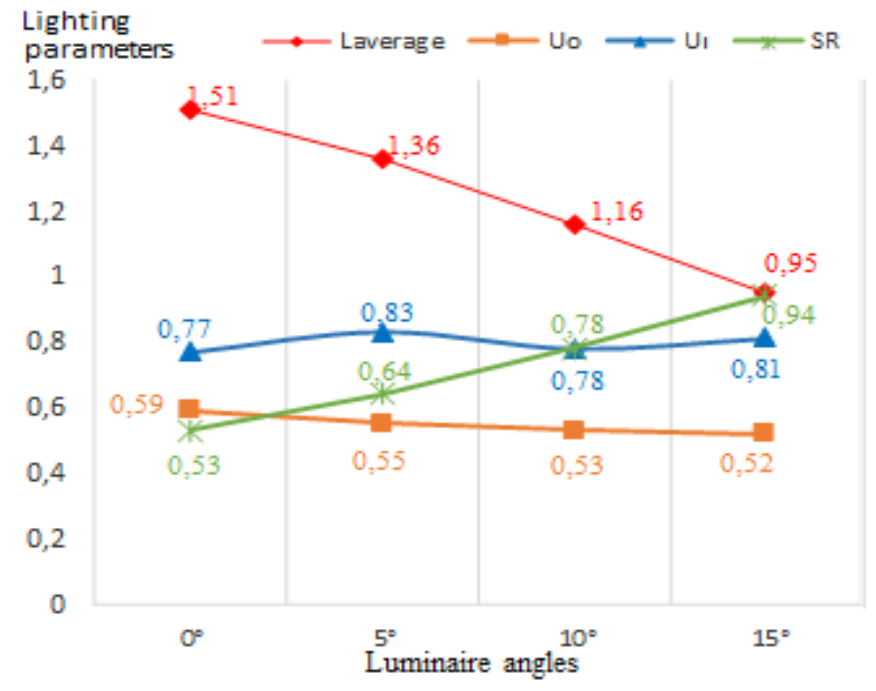

Fig.6. The change of the lighting parameters according to the luminaire angles

TABLE V

ILLUMINANCE LEVEL FOR TUNNEL LIGHTING (LUMINAIRE ANGLE: $0^{\circ}$ )

\begin{tabular}{|c|c|c|c|c|c|c|c|c|c|c|}
\hline \multicolumn{6}{|c|}{ Emin=15,94 Lx Emax $=41,40 \mathrm{Lx}$} & $\mathrm{E}_{\text {average }}=29,08 \mathrm{Lx}$ & Uoa $=0,55$ & $\mathrm{Ula}=0,38$ & $\mathrm{SR}=0,53$ & Angle: $0^{\circ}$ \\
\hline Observer location (m) & 0,550 & 1,650 & 2,750 & 3,850 & 4,950 & 6,050 & 7,150 & 8,250 & 9,350 & 10,450 \\
\hline 0,667 & 25,897 & 19,360 & 23,902 & 20,434 & 15,937 & 15,937 & 20,435 & 23,905 & 19,365 & 25,902 \\
\hline 2,000 & 34,774 & 31,556 & 33,584 & 28,075 & 22,387 & 23,583 & 29,504 & 37,240 & 33,709 & 36,287 \\
\hline 3,333 & 36,951 & 34,211 & 41,400 & 33,165 & 29,603 & 29,604 & 33,167 & 41,404 & 34,216 & 36,958 \\
\hline
\end{tabular}


TABLE VI

LUMINANCE (LUMINAIRE ANGLE: $0^{\circ}$ ) FOR TUNNEL LIGHTING

\begin{tabular}{|c|c|c|c|c|c|c|c|c|c|c|}
\hline \multicolumn{10}{|c|}{$\mathbf{L}_{\text {average }}=\mathbf{1 , 5 1} \mathbf{~ c d} / \mathbf{m}^{2} \quad U_{0}=0,59 \quad U_{1}=0,77$} & Angle: $0^{\circ}$ \\
\hline Observer location (m) & 0,550 & 1,650 & 2,750 & 3,850 & 4,950 & 6,050 & 7,150 & 8,250 & 9,350 & 10,450 \\
\hline 0,667 & 1,068 & 0,987 & 1,117 & 1,026 & 0,912 & 0,954 & 1,149 & 1,177 & 0,894 & 1,050 \\
\hline 2,000 & 1,667 & 1,698 & 1,781 & 1,669 & 1,584 & 1,737 & 1,930 & 2,055 & 1,718 & 1,700 \\
\hline 3,333 & 1,641 & 1,659 & 1,895 & 1,679 & 1,631 & 1,797 & 1,907 & 2,084 & 1,624 & 1,623 \\
\hline
\end{tabular}

TABLE VII

LUMINANCE (LUMINAIRE ANGLE: $5^{\circ}$ ) FOR TUNNEL LIGHTING

\begin{tabular}{|c|c|c|c|c|c|c|c|c|c|c|}
\hline \multicolumn{8}{|c|}{$\mathbf{L}_{\text {average }}=\mathbf{1 , 3 6} \mathbf{~ c d} / \mathbf{m}^{\mathbf{2}}$ Uo $=0,55$} & U1 $=0,83$ & \multicolumn{1}{c|}{ TI = \%3,0 } & Angle:5 $^{\circ}$ \\
\hline Observer location (m) & 0,550 & 1,650 & 2,750 & 3,850 & 4,950 & 6,050 & 7,150 & 8,250 & 9,350 & 10,450 \\
\hline 0,667 & 0,896 & 0,839 & 0,928 & 0,873 & 0,758 & 0,781 & 0,944 & 0,946 & 0,749 & 0,879 \\
\hline 2,000 & 1,466 & 1,475 & 1,579 & 1,499 & 1,396 & 1,483 & 1,664 & 1,683 & 1,414 & 1,441 \\
\hline 3,333 & 1,584 & 1,582 & 1,843 & 1,637 & 1,634 & 1,787 & 1,844 & 2,037 & 1,546 & 1,555 \\
\hline
\end{tabular}

TABLE VIII

LUMINANCE (LUMINAIRE ANGLE: $10^{\circ}$ ) FOR TUNNEL LIGHTING

\begin{tabular}{|c|c|c|c|c|c|c|c|c|c|c|}
\hline \multicolumn{8}{|c|}{$\mathbf{L}_{\text {average }} \mathbf{= 1 , 1 6} \mathbf{~ c d} / \mathbf{m}^{\mathbf{2}} \mathrm{Uo}=0,53$} & $\mathrm{U}=0,78$ & $\mathrm{TI}=\% 3,0$ & Angle: $10^{\circ}$ \\
\hline Observer location $(\mathrm{m})$ & 0,550 & 1,650 & 2,750 & 3,850 & 4,950 & 6,050 & 7,150 & 8,250 & 9,350 & 10,450 \\
\hline 0,667 & 0,714 & 0,696 & 0,734 & 0,708 & 0,627 & 0,642 & 0,723 & 0,702 & 0,614 & 0,695 \\
\hline 2,000 & 1,293 & 1,180 & 1,320 & 1,258 & 1,160 & 1,224 & 1,360 & 1,381 & 1,081 & 1,260 \\
\hline 3,333 & 1,447 & 1,432 & 1,643 & 1,470 & 1,463 & 1,595 & 1,643 & 1,799 & 1,410 & 1,411 \\
\hline
\end{tabular}

TABLE IX

LUMINANCE (LUMINAIRE ANGLE: $15^{\circ}$ ) FOR TUNNEL LIGHTING

\begin{tabular}{|c|c|c|c|c|c|c|c|c|c|c|}
\hline \multicolumn{8}{|c|}{$\mathbf{L}_{\text {average }} \mathbf{= 0 , 9 5} \mathbf{~ c d / \mathbf { m } ^ { 2 }}$ Uo $=0,52$} & U1 $=0,81$ & TI = \%3,1 & ${\text { Angle: } 15^{\circ}}^{\circ}$ \\
\hline Observer location (m) & 0,550 & 1,650 & 2,750 & 3,850 & 4,950 & 6,050 & 7,150 & 8,250 & 9,350 & 10,450 \\
\hline 0,667 & 0,577 & 0,567 & 0,597 & 0,602 & 0,544 & 0,554 & 0,603 & 0,554 & 0,499 & 0,558 \\
\hline 2,000 & 1,083 & 0,982 & 1,080 & 1,040 & 0,942 & 0,976 & 1,093 & 1,102 & 0,894 & 1,051 \\
\hline 3,333 & 1,243 & 1,172 & 1,345 & 1,247 & 1,198 & 1,319 & 1,372 & 1,433 & 1,131 & 1,195 \\
\hline
\end{tabular}

\section{DISCUSSIONS}

In this study, the effects of angled lighting in tunnel lighting were investigated. For this purpose, the parameters of a road used for single-lane military purposes (for underground arsenals) were processed into a lighting simulation. Firstly, the optimum distance was determined as $11 \mathrm{~m}$ when the angle of the luminaire was $0^{\circ}$. When the angle of the luminaire is $0^{\circ}$ and the distance between the luminaires is $11 \mathrm{~m}$, all values are suitable for CIE 88-2004 standard. If the luminaire angle is $5^{\circ}$, $10^{\circ}$ and $15^{\circ}$, the distance between the poles falls below the average value of $L_{\text {average }}=1.50 \mathrm{~cd} / \mathrm{m}^{2}$. Luminaire angle $5^{\circ}$ $L_{\text {average }}=1.36 \mathrm{~cd} / \mathrm{m}^{2}$; luminaire angle $10^{\circ} L_{\text {average }}=1.16 \mathrm{~cd} / \mathrm{m}^{2}$; luminaire angle $15^{\circ} \quad L_{\text {average }}=0.95 \mathrm{~cd} / \mathrm{m}^{2}$; value falls. $L_{\text {average }}=1.50 \mathrm{~cd} / \mathrm{m}^{2}$ falling below does not comply with CIE standards. Accordingly, when the luminaire angle is $0^{\circ}$, the highest lighting efficiency is reached and the luminous efficiency decreases as the angle increases.

This work for the tunnel can be applied on all roads. Angled lighting is used in about $90 \%$ of the currently roads. As stated in this example, angled lighting $\left(5^{\circ}, 10^{\circ}\right.$ and $\left.15^{\circ}\right)$ with $70 \mathrm{~W}$ HPS lamp corresponds to tunnel lighting with 50 W HPS lamp (not angled, $0^{\circ}$ ). Using higher power lighting increases energy consumption. Increased energy consumption is undesirable in terms of efficiency.

\section{CONCLUSION}

The most accurate reference to road-tunnel lighting and lamp selection is the international standards. For this reason, simulation road lighting is adapted to CIE standards. According to CIE 88-2004 standard, luminance values, average luminance level, average and longitudinal uniformity values of all scores were calculated for the observers. The data of the lamp used were processed in the simulation database and the results were analyzed.

The $50 \mathrm{~W}$ HPS lamp complies with the standards specified in the CIE 88-2004 The Lighting of Road Tunnels and Underpasses at the luminaire angle $=0^{\circ}$ optimum pole pitch (11m).

If the angle of the luminaire is $5^{\circ}, 10^{\circ}$ and $15^{\circ}$, the $L_{\text {average }}$ is less than $1.50 \mathrm{~cd} / \mathrm{m}^{2}$. This doesn't fit the CIE standards. Inefficient and inadequate lighting was observed under the standards.

Such special solutions can be improved by lighting simulations. Therefore, as in this example, special solutions should be analyzed in road lighting in simulation environments.

\section{REFERENCES}

[1] M.S. Cengiz, "A Simulation and Design Study for Interior Zone Luminance in Tunnel Lighting." Light \& Engineering, vol. 27. 2, 2019, pp. 42-51.

[2] M.S. Cengiz, "The Relationship Between Maintenance Factor and Lighting Level in Tunnel Lighting." Light \& Engineering, vol. 27. 3, 2019.

[3] M.S. Cengiz, Ç. Cengiz, "Numerical Analysis of Tunnel LED Lighting Maintenance Factor." IIUM Engineering Journal, vol. 19. 2, 2018, pp. 154-163.

[4] S Onaygil, Ö Güler, E. Erkin, "Determination of the effects of structural properties on tunnel lighting with examples from Turkey." Tunnelling and underground space technology, vol. 18. 1, 2003, pp. 85-91.

[5] S. Onaygil, "Parameters affecting the determination of the tunnel threshold-zone luminance." Turkish Journal of Engineering and Environmental Sciences, vol. 24. 2, 2000, pp. 119-126.

[6] A. Ongun, "The Analysis of Optımum Solution Criteria for The Designing of Road Lighting Installations." M. Sc. Thesis, Gazi University Institute of Science and Technology, 2007. 174 pages. Ankara. 
[7] International Commission on Illumination, Road lightings as an Accident Countermeasure, CIE 93, Vienna-Austria, 92 (1992).

[8] M.S. Cengiz, "Effects of Luminaire Angle and Illumination Topology on Illumination Parameters in Road Lighting." Light \& Engineering, 2019.

[9] K.A. Painter, D.P. Farrington, "Evaluating Situational Crime Prevention A Young People's Survey.", The British Journal of Criminology, London, vol. 41, 2, 2001, pp. 266-284.

[10] Gan, F., Grabosky, P., Improved street Lighting and Crime Reduction, The Promise of Crime Prevention, $2^{\text {nd }}$ ed. ISBN 0642241724, Canberra: Australian Institute of Criminology, Canberra,1326-6004 (2000).

[11] G. Gencer M. Eren, S. Yildirim. M. Kaynaklı.O. Palta, M.S. Cengiz, Ç. Cengiz, Numerical Approach to City Road Lighting Standards, Book of Abstracts, Imeset Int. Conf. Mult. Sci. Eng. Tech., October 27-29, 2017, Bitlis, Turkey.

[12] M. Eren, M. Kaynaklı, I. Yapici, G. Gencer, Y. Yurci, M.S. Cengiz, C. Cengiz, Numerical Analysis of Maintanance Factor for Tunnel and Road In Solid State Lighting. International Conference on Multidisciplinary, Science, Engineering and Technology 2017, Bitlis, 2017, October 27-29, Turkey.

[13] G. Leonid, S. Sergei, A. Feofanov, "Reconstruction of Illumination Devices at the Moscow Metro." Light \& Engineering, vol. 27. 2, 2019, pp. 52-57.

[14] W.V. Bommel, Road Lighting: Fundamentals, Technology and Application, Springer Int. Pub. Switzerland-2015, 333 pages, ISBN: 978-3-319-11465-1

[15] M. Özkaya, "Aydınlatma Tekniği." Birsen Yayınevi, İstanbul-1994, 91.

[16] E. Tetri, S.B. Chenani, R.S. Rasanen, "Advancement in Road Lighting." Light \& Engineering, vol. 26. 1, 2018, pp. 99-109.

[17] W.V. Bommel, G.V. DenBeld, M.V. Ooyen, "Industrial Light and Productivity." Lighting \& Engineering, vol. 11. 1, 2003, pp. 14-21.

[18] P. Barua, S. Mazumdar, S. Chakraborty, S. Bhattacharjee, "Road Classification Based Energy Efficient Design and its Validation for Indian Roads.” Light \& Engineering, vol. 26. 2, 2018, pp. 110-121.

[19] G.I. Rossi, P. Soardo, "Energy Saving and Environmental Compatibility in Road Lighting." Light \& Engineering, vol. 20. 4, 2012, pp. 55-63.

[20] S. Onaygil, "Yol aydınlatma projelerinde yol sinıfinın belirlemesinin önemi.” Kaynak Elektrik Dergisi, vol. 12, 1998, pp. 125-132.

[21] Ö. Güler, S. Onaygil, "The effect of luminance uniformity on visibility level in road lighting." Lighting Research \& Technology, vol. 35. 3, 2003, pp. 199-213.

[22] B. Buyukkinaci, S. Onaygil, Ö. Guler, M.B. Yurtseven, "Determining minimum visibility levels in different road lighting scenarios, Lighting Research \& Technology vol. 50. 7, 2018, pp. 1045-1056.

[23] Gencer, G., Eren, M., Yildirim, S., Kaynaklı, M., Palta, O., Cengiz, M.S., Cengiz, Ç. 2017. Numerical Approach to City Road Lighting Standards, In: International Conference on Multidisciplinary, Science, Engineering and Technology 2017, Bitlis, October 27-29, Turkey

[24] CIE Technical Report-88-2004. Guide for the Lighting of Road Tunnels and Underpasses [R], 2004.

[25] CIE 140-2000 Road Lighting Calculations. CIE140, International Commission on Illumination, Road Lighting Calculations, ViennaAustria, 33 (2000).

[26] P. Thorns, "Review of the Current State and Future Development in Standardising Artificial Lighting.” Light \& Engineering, vol. 27. 2, 2019, pp. 4-22.

[27] CIE 115-2010 CIE115, International Commission on Illumination, Recommendations far the Lighting of Roads for Motor and Pedestrian Traffic, Vienna-Austria, 1995, 25.

[28] CIE 136-2000, Guide to the lighting of urban areas, 3 August 2000.

[29] S. Onaygil, TEDAŞ Genel Müdürlüğü Meslek İçi Eğitim Semineri, TEDAŞ Basımevi, Ankara, 2005. pp. 1-70.

[30] S. Onaygil, TEDAŞ Genel Müdürlüğü Meslek İçi Eğitim SemineriGölbaşı Eğitim Tesisleri, Yol aydnlatma Semineri 23-24 Ocak 2007

[31] CIE 194-2011 On site measurement of the photometric properties of road and tunnel lighting, 2011.

[32] S.B. Efe, "Dinamik güç sistemleri için Jakoben yöntemi tabanlı birleşik güç akış kontrolörü tasarımı.” DÜMF Mühendislik Dergisi, vol.9. 2, 2018, pp. 601-607.

[33] S.B. Efe, " UPFC Based Real-Time Optimization of Power Systems for Dynamic Voltage Regulation." vol.116. 3, 2018, pp.391-406.

[34] M.S. Cengiz, "Smart meter and cost experiment." Przeglad Elektrotechniczny, vol. 89. 11, 2013, pp. 206-209.

[35] M.S. Cengiz, M.S. Mamiş, "Endüstriyel tesislerde verimlilik ve güneş enerjisi kullanımı." VI. Enerji Verimliliği Kalitesi Sempozyunu ve Sergisi, 21-25. 4-6 Haziran 2015, Sakarya, Türkiye
[36] M.S. Cengiz, M.S. Mamiş, "Solution Offers For Efficiency and Savings in Industrial Plants." Bitlis Eren University Journal of Science and Technology, vol. 5. 1, 2015, pp. 24-28.

[37] M. Çıbuk, "Tek Atlamalı Kablosuz Algılayıcı Ağlarda Yeni Bir Hızlı Ağa Katılım Algoritması." Bitlis Eren Üniversitesi Fen Bilimleri Dergisi." Vol. 7. 1, 2018, pp. 72-83.

[38] Ö.F. Ertuğrul., "Forecasting electricity load by a novel recurrent extreme learning machines approach." International Journal of Electrical Power \& Energy Systems, vol. 78. 7, 2016, pp. 429-435.

[39] M.S. Cengiz, "Evaluation of Smart Grids and Turkey." Global Advanced Research Journal of Engineering Technology and Innovation, vol. 3. 7, 2014, pp. 149-153.

[40] B. Turan, H.İ. Eskikurt, M.S. Can, 'Dizüstü Bilgisayar Ekranında Bakılan Nokta Koordinatlarının Yapay Sinir Ağı ile Tahmin Edilmesi." 2014 IEEE $22^{\text {nd }}$ Signal Processing and Communications Applications Conference (SIU 2014), Yayın No:1294070.

[41] M.S. Can, B.Turan, Y.S. Ari (2013). Evler Ve Soğuk Hava Depolari İçin Sms ve Mikrodenetleyici Tabanli Buzdolabi Soğutucu Ariza Uyari Sistemi. Otomatik Kontrol Ulusal Toplantıs1, TOK 2013.

[42] D. Arı, M. Çıbuk, F. Ağgün, "Effect of Relay Priority Mechanism on Multi hop Wireless Sensor Networks." Bitlis Eren University Journal of Science and Technology, vol. 7. 2, 2017, pp. 145-153.

\section{BIOGR APHIES}

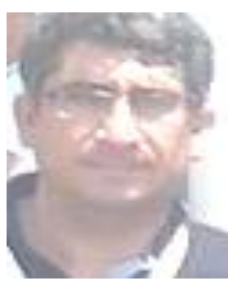

MEHMET SAIT CENGIZ is the Director of Research and Development 2000-2010 years in Turkey Electricity Distribution Company. In 2011, he completed his master degree in the field of Electrical and Electronics Engineering. In 2016, he completed his doctorate degree in Inonu University, Institute of Science and Technology, Electrical and Electronics Engineering. Works in the field of applied lighting. He is currently working at Bitlis Eren University. 